\title{
Reimplantasi gigi avulsi Reimplantation of avulsed teeth
}

\author{
${ }^{1}$ Fonny Dahong, ${ }^{2}$ Lies Wahyuni Winarso \\ ${ }^{1}$ Bagian Bedah Mulut \\ ${ }^{2}$ Mahasiswa tahapan profesi \\ Fakultas Kedokteran Gigi Universitas Hasanuddin \\ Makassar, Indonesia
}

\begin{abstract}
It is well known dental reimplantation is indicated following traumatic avulsion by the preservation of vitality in the periodontal ligament with condition asepsis. Reimplantation refers to the insertion and temporary of completely or partially avulsed teeth that have resulted from traumatic injury. Dental reimplantation of an avulsed tooth depends on certain clinical conditions like physiological status of periodontal ligament, the stage of root development and the length of extra oral time. Depending on the patient's age, retention of the permanent incisor can maintain the aesthetic appearance, occlusal function and alveolar ridge height. Though the risk of progressive replacement resorption and subsequent tooth loss is high after a long dry storage. This article presents management of one case with avulsed permanent incisors that were storage in dry condition for seventeen hours.
\end{abstract}

Key words: dental reimplantation, avulsion tooth, dry storage

\begin{abstract}
ABSTRAK
Telah diketahui secara umum reimplantasi gigi diindikasikan untuk gigi avulsi akibat trauma yang terjaga vitalitas dan kondisi asepsis dari selular ligamentum periodontal. Reimplantasi berhubungan dengan suatu tindakan insersi dan fiksasi sementara dari gigi yang avulsi total maupun parsial, yang disebabkan oleh suatu cedera traumatik. Dental reimplantasi gigi avulsi bergantung pada kondisi klinik tetentu, misalnya status fisiologi dari ligamentum periodontal, tingkat perkembangan akar gigi, dan lamanya gigi tersebut berada di luar mulut, serta tergantung pula pada umur pasien, retensi dari insisivus permanen yang dapat mempertahankan penampilan estetik maupun fungsi oklusal serta tingginya lingir alveolar. Meskipun demikian, ada risiko dari pengertian resorpsi progresif penempatan kembali dan kemungkinan besar kehilangan gigi setelah penyimpanan dalam waktu yang lama. Artikel ini mempresentasikan suatu laporan kasus reimplantasi gigi insisivus permanen yang avulsi setelah disimpan dalam kondisi kering selama 17 jam. Implantasi berhasil dan gigi tersebut dapat digunakan kembali seperti sebelumnya.
\end{abstract}

Kata kunci: reimplantasi gigi, gigi avulsi, penyimpanan kering

Koresponden: Fonny Dahong, Bagian Bedah Mulut dan Maksilofasial, Fakultas Kedokteran Gigi Universitas Hasanuddin, Jl. Kandea No.5, Makassar, Indonesia. E-mail: fonnydh@gmail.com

\section{PENDAHULUAN}

Reimplantasi atau replantasi merupakan suatu tindakan di bidang kedokteran gigi yang merujuk pada pemasangan atau insersi dan fiksasi sementara gigi yang mengalami avulsi, baik sebagian atau keseluruhan akibat suatu trauma. Kejadian avulsi gigi ini dapat terjadi pada semua umur. Gigi yang paling sering avulsi adalah gigi depan rahang atas. ${ }^{1}$

Reimplantasi merupakan perawatan pilihan untuk penanganan gigi avulsi, yang bertujuan untuk mengembalikan fungsi fisiologis gigi. Istilah avulsi gigi dapat digunakan untuk menunjukkan suatu keadaan terlepasnya gigi alami dari soketnya akibat trauma. Kejadian avulsi pada gigi alami dapat memutuskan serat ligamentum periodontal dan bundel neurovaskular, serta dapat pula mencederai tulang alveolar serta gigi di sekitarnya. Ketika gigi lepas dari soketnya, sel-sel pulpa dan ligamentum periodontal mulai mengalami kerusakan akibat kekurangan asupan darah. Faktor yang lain adalah kekeringan pada gigi avulsi, akibat penyimpanan gigi avulsi yang salah, dan kontaminasi dengan bakteri merupakan hal-hal yang penting untuk penyembuhan ligamentum periodontal yang baik serta keberhasilan reimplantasi. ${ }^{2,3}$

Artikel laporan kasus ini akan memaparkan penatalaksanaan dan hasil perawatan gigi insisivus sentralis dan lateralis yang mengalamia avulsi akibat mengalami trauma.

\section{KASUS}

Seorang pasien laki-laki umur 19 tahun datang ke klinik gigi jam 9 pagi, dengan keluhan gigi depan rahang atas terlepas tetapi tidak membawa gigi-gigi tersebut, akibat kecelakaan lalu lintas semalam, kira-kira jam 23. Bibir rahang atas dan bawah mengalami luka dan bengkak.

Hasil pemeriksaan klinis adalah keadaan umum baik, tensi $110 / 70 \mathrm{mmHg}$, nadi $70 \mathrm{x} / \mathrm{menit}$, palpasi kelenjar limfa kiri dan kanan terasa lunak dan sakit. 
Didapati luka pada mukosa bibir rahang atas dan bawah. Gigi 11 dan 12 goyang derajat 2, gigi 21 dan 22 terlepas dari soketnya, mukosa gingiva regio gigi depan rahang atas tidak tampak adanya kelainan. Pasien dianjurkan untuk mencari gigi yang avulsi di tempat kecelakaan, dan dimasukan ke dalam larutan saline. Selain itu pasien dirujuk untuk injeksi anti tetanus. Jam 14, pasien kembali ke klinik dengan menyerahkan gigi 21 dan 22 tersebut. Gigi tersebut dalam keadaan baik, tidak ditemukan fraktur mahkota dan akar. Pemeriksaan foto ronsen (gambar 1A), nampak soket gigi 21 dan gigi 22 tidak ada kelainan, dan tidak ada fraktur alveolar.

\section{PENATALAKSANAAN}

Setelah dilakukan pembersihan gigi 21 dan gigi 22 dengan larutan saline, dilakukan perawatan endodontik di luar mulut untuk kedua gigi tersebut. Preparasi saluran akar, ekstirpasi, pengisian dengan guttap percha point dengan sealer endomethasone, dan penutupan ujung foramen periapikal dengan semen ionomer kaca.

Setelah tahapan endodontik dilakukan anestesi lokal pada regio gigi 21 dan gigi 22, kemudian dilakukan pembersihan soket gigi dari bekuan darah, dengan larutan saline solution. Selanjutnya gigi 21 dan 22 diinsersikan ke dalam soketnya, dan dilakukan penyesuaian oklusi, kemudian difiksasi dengan orthodontic bracket.

Untuk mengatasi infeksi dan rasa nyeri diresepkan beberapa obat, yaitu Cefadroxil kapsul $500 \mathrm{mg} 2 \times 1$ selama 5 hari, asam mefenamat tablet $500 \mathrm{mg}$ 2x1 selama 5 hari, obat kumur Minosep.
Pasien diinstruksikan untuk tidak mengunyah dan menggigit menggunakan gigi-gigi depan atas, serta untuk sementara hanya mengkonsumsi makanan lunak.

Pada kontrol hari ke-2, dilakukan pemeriksaan foto ronsen (Gambar 1B) dengan hasil posisi gigi 21 dan 22 normal, gingiva regio gigi depan atas sedikit bengkak, serta bibir bengkak. Pada kontrol hari ketujuh didapati nyeri gigi depan atas telah berkurang, namun luka pada bibir belum sembuh. Pada kontrol hari ke 14 didapati gigi depan atas goyang derajat 2 dan ngilu jika diperkusi.

Pada kontrol hari ke-30, gigi 21 dan 22 tidak goyang. Pemeriksaan foto ronsen ketiga (gambar 2) tidak didapati kelainan periapikal, orthodontic bracket dilepas. Sedangkan pada kontrol bulan ke6 , pasien sudah dapat mengunyah dengan gigi-gigi anterior tanpa keluhan. Pemeriksaan foto ronsen keempat, tidak tampak kelainan periapikal.

\section{PEMBAHASAN}

Reimplantasi gigi avulsi merupakan suatu tindakan insersi gigi avulsi ke dalam soketnya. Pada kasus tersebut seorang pasien umur 19 tahun, mengalami avulsi gigi 21 dan 22 karena kecelakaan lalu lintas. Reimplantasi merupakan perawatan pilihan pertama untuk mempertahan gigi tersebut, serta, mengembalikan fungsi-fungsi normal gigi. Untuk menentukan keberhasilan reimplantasi tersebut perlu diperhatikan beberapa hal, yaitu gigi avulsi tersebut harus sehat tanpa karies, mahkota atau akar tidak mengalami kepatahan, tidak ada kelainan periodontal, soket gigi avulsi tetap utuh, gigi avusi sebaiknya tidak mengalami kelainan
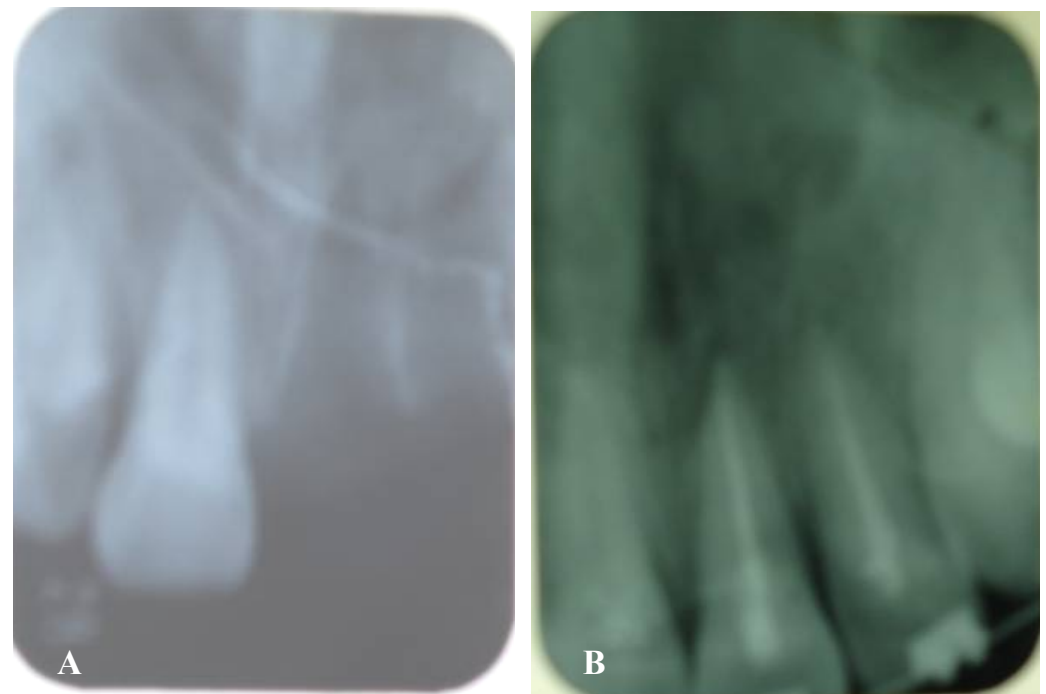

Gambar 1A Foto ronsen soket gigi 21 dan 22 nampak normal; B foto ronsen setelah pemasangan gigi 21 dan 22, tampak kedua gigi menempati posisinya kembali. 


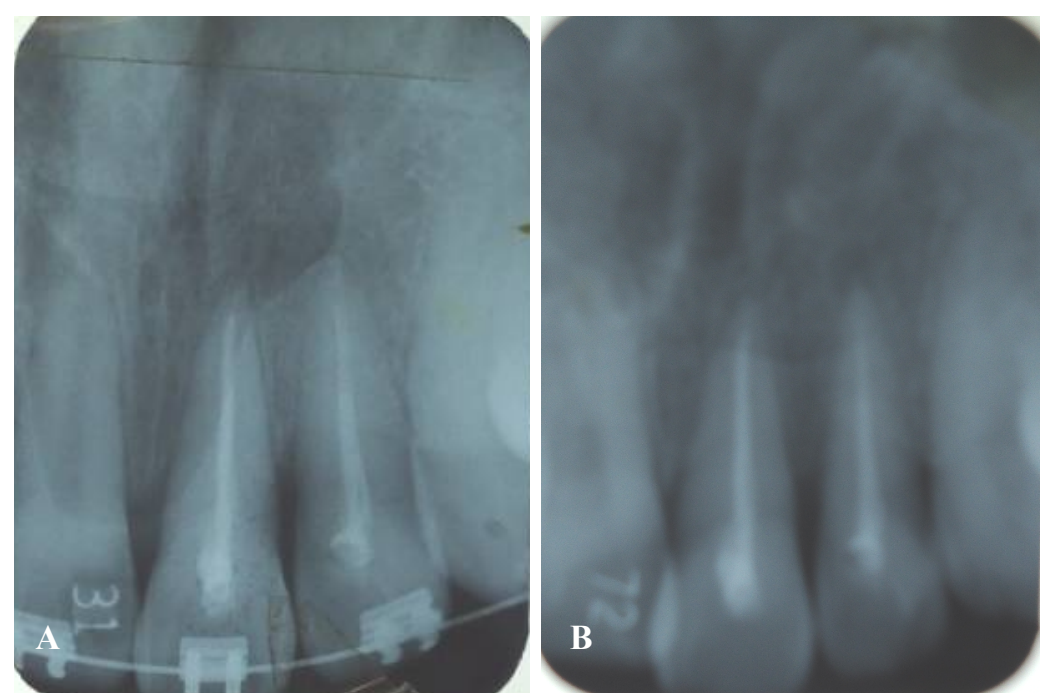

Gambar 2 A Gambar foto ronsen kontrol ke-3 dan B foto ronsen ke-4 tidak menampakkan kelainan periapikal.

kelainan ortodontik, waktu gigi berada di luar mulut tidak lebih 60 menit, media penyimpanan gigi avulsi harus tetap sama. Beberapa media penyimpanan yang dapat digunakan, yaitu saliva, susu, dan larutan saline. ${ }^{1,4,5}$

Meskipun pada kasus tersebut, waktu di luar mulut gigi avulsi tersebut melampaui ketentuan, tetapi beberapa kepustakaan telah melaporkan keberhasilan kasus semacam itu. ${ }^{1,3}$

Pada saat melakukan tindakan reimplantasi perlu diperhatikan penatalaksanaan soket gigi, yaitu tidak melakukan kuretasi pada soket gigi, tidak mengeringkan soket, sebaiknya melakukan irigasi dengan saline. Pertimbangan perawatan endodontik sebelum atau sesudah tindakan reimplantasi, hal ini tergantung lamanya gigi avulsi di luar mulut atau secepatnya diinsersi kembali. Bilamana dalam waktu singkat ligamentum periodontal masih hidup, gigi avulsi dapat direimplantasikan tanpa perawatan endodontik. ${ }^{1,6}$

Pada kasus ini gigi avulsi di luar mulut berada dalam lingkungan yang tidak adekuat, selama 15 jam, maka diputuskan untuk dilakukan perawatan endodontik sebelum gigi-gigi direimplantasikan. Perawatan endodontik diawalu dengan ekstirpasi, pengisian saluran akar dengan guttap percha point dan endomethason, kemudian root ending atau ujung akar dengan menggunakan gelas ionomer (Fuji 9). Beberapa bahan root end filling yang dapat digunakan adalah amalgam, zinc oxide eugenol cement, polycarboxylate cement, semen ionomer kaca, dan mineral trioxide aggregate (MTA). MTA merupakan bahan yang terbaik sebagai bahan root end filling. ${ }^{7}$

Fiksasi gigi avulsi dapat dilakukan dengan wiring atau orthodontik brake, dianjurkan selama dilakukan selama 7-14 hari bila tidak ada patah tulang alveolar. Bilamana gigi tetap goyang, dapat difiksasi lebih lama, dan pasien dipesan untuk tidak mengigit pada gigi tersebut. ${ }^{1}$

Untuk mencegah kemungkinan infeksi, kepada pasien dilakukan suntikan anti tetanus, dan antibiotika juga dilakukan, berhubung pasien selain mengalami luka pada mulut, juga terdapat luka pada siku.

Dari hasil perawatan yang telah dilakukan, disimpulkan bahwa reimplantasi merupakan pilihan utama perawatan gigi avulsi. Beberapa faktor yang harus diperhatikan dalam melakukan tindakan reimplantasi, antara lain kondisi gigi yang avulsi, keadaan tulang alveolus dan jaringan periodontal, media penyimpanan, lamanya gigi avulsi di luar mulut, penatalaksanaan soket gigi, dan waktu dilakukannya perawatan endodontik. Kunci keberhasilan reimplantasi terletak pada vitalitas selsel ligamentum periodontal, serta dua faktor penting yaitu tingkat kerusakan ligamentum periodontal akibat trauma, dan lamanya gigi avulsi di luar mulut. Waktu di luar mulut sebaiknya tidak melebihi 60 menit. Media penyimpanan gigi avulsi juga memegang peranan penting; oleh karena media yang paling baik adalah saliva pasien sendiri, maka dianjurkan gigi avulsi diletakkan pada vestibulum ronga mulut. Penyesuaian oklusi serta fiksasi harus pula diperhatikan, karena lamanya fiksasi gigi untuk tulang alveolus yang sehat adalah 7-10 hari.

Disebabkan data yang tersedia, berdasarkan klasifikasi Ellis, kasus avulsi gigi anterior rahang atas berkisar 16\% dalam kasus trauma kecelakaan. 
Oleh karena itu perlu disosialisasikan kepada masyarakat tentang pertolongan pertama pada kasus avulsi total, yaitu gigi avulsi tersebut harus disimpan di dalam rongga mulut, atau larutan susu, dan segera ke dokter gigi terdekat untuk direimplantasikan.

\section{DAFTAR PUSTAKA}

1. Grossman LI, Rio OSD. Ilmu endodontik dalam praktek. $11^{\text {th }}$ Ed. Alih bahasa: Abyono R. Jakarta : Penerbit Buku Kedokteran EGC; 1995. p. 358-65.

2. Andersen JO. Dental injuries a manual. $3^{\text {rd }}$ Ed. Copenhagen: Munk Sgaend; 2002. p. 54-5.

3. Adil NF, Ahmed SS, Jindal MK, Arshad SH, Delayed replantation of avulsed teeth. J Indian Soc Pedodont Prev Dent 2007; 25; 17-9. Available from: URL : http://www.jisppd.com/text asp/2007/25/5/17/3474

4. Fonseca JR, Walker VR. Oral and maxillofacial trauma, Vol 1. Philadelphia: W B Saunders Co; 1997. p. $341-3$.

5. Spiller MS. Avulsed teeth [monograph on the Internet]. 2000. Available from: URL : www.doctorspiller.com.

6. Weine FS. Endodontic therapy. $6^{\text {th }}$ Ed. St. Louis: Mosby; 2004. p. 85-93.

7. Glickman GN, Hartwell GR. Endodontic surgery. In: Ingle JI, Bakland LK, Baumgartne JC. Endodontics. $6^{\text {th }}$ Ed. Hamilton: BC Decker Inc; 2008. p. 1261-5. 